\author{
MACIEJ SKORY \\ ORCID: 0000-0002-1116-3169 \\ Uniwersytet Wrocławski
}

\title{
O POTRZEBIE WERYFIKACJI ZASAD WYODRĘBNIENIA OBROTU GOSPODARCZEGO (KWALIFIKOWANEGO)
}

\begin{abstract}
Abstrakt: $\mathrm{W}$ opracowaniu podjęto problematykę miejsca prawa handlowego w systemie prawa. Analizie, także w ujęciu historycznym, poddano różne sposoby wydzielenia prawa handlowego, nazw stosowanych na określenie tej części prawa oraz kryteriów kwalifikacji stosunków handlowych. W dalszej części omówiono wpływ regulacji konsumenckich na definiowanie przedsiębiorcy oraz znaczenie, jakie to ma dla wyodrębnienia obrotu gospodarczego (kwalifikowanego), a także ryzyk związanych z tym procesem. W ostatniej części zaproponowano alternatywne sposoby wyodrębniania obrotu gospodarczego, wskazując również na potrzebę ujednolicenia regulacji, odejścia od systemu monistycznego oraz rozszerzenia mechanizmów ochronnych właściwych stosunkom konsumenckim także na relacje dwustronnie gospodarcze, przy zastosowaniu kryterium stopnia zorganizowania danego podmiotu.
\end{abstract}

Słowa kluczowe: prawo handlowe, prawo gospodarcze, przedsiębiorca, konsument, zasada monizmu prawa prywatnego, kryteria wyodrębnienia obrotu kwalifikowanego

\section{O PORZĄDKOWANIU PRAWA}

Wyodrębnienie prawa gospodarczego w ramach szeroko pojętego prawa prywatnego jest naturalną potrzebą wynikającą zarówno z powodów natury pragmatycznej, uwzględniającej specyfikę tego obszaru prawa, jak i pierwotną ludzką potrzebą porząakowania materii według różnego rodzaju kryteriów. Porządkowanie, selekcjonowanie, grupowanie, kategoryzowanie, przyporządkowywanie do określonych grup według pewnych cech badanego zjawiska jest bowiem zarówno koniecznym elementem procesu poznawczego (analitycznego), jak i następującego po nim procesu wykorzystywania (eksploatacji) określonych zasobów wiedzy. Szczególnie odnosi się to do tak niemierzalnych, abstrakcyjnych i umownych zjawisk jak prawo, których nie sposób doznać organoleptycznie, zweryfikować zmysłami ich natury oraz istotnych cech. Truizmem czy wręcz aksjomatem jest ogólne stwierdzenie o potrzebie porządkowania świata realnego oraz odpowiadającego 
mu świata idei, w których funkcjonujemy. Odnosi się to zwłaszcza do nauki, która opiera się przecież na poznaniu oraz opisywaniu otaczającej nas rzeczywistości. Problemem nie jest zatem pytanie, czy dokonywać podziału, wyodrębnienia, uporządkowania oraz kwalifikacji, ale w jaki sposób to czynić, jakich używać do tego narzędzi, jakie kryteria zastosować i przede wszystkim jakim celom służyć ma uporządkowany opis rzeczywistości. W szeroko pojętym obszarze prawa, to jest przepisów, norm prawnych, grup norm (instytucji), konstrukcji teoretycznych itp., niewątpliwie jednym z celów jest ułatwienie nauczania tych zjawisk (wzgląd na aspekt edukacyjny). Drugim, jak się wydaje — znacznie ważniejszym, jest usprawnienie procesu posługiwania się tymi abstrakcyjnymi pojęciami i sprowadzenie pewnych terminów, mechanizmów myślowych do tak zwanego wspólnego mianownika ułatwiającego $\mathrm{w}$ danym obszarze poruszanie się $\mathrm{w}$ gąszczu regulacji (wzgląd na aspekt praktyczny). Trzecim, nieraz pomijanym motywem porządkowania, podziałów i kwalifikacji jest ułatwienie procesu twórczego, rozwijania danej dziedziny przez opracowywanie nowych konstrukcji mogących mieć znaczenie dla opisania oraz uregulowania prawnego nowych zjawisk przyrodniczych i społecznych ${ }^{1}$.

\section{O MIEJSCU PRAWA HANDLOWEGO W SYSTEMIE PRAWA}

Przenosząc zarysowane w skrócie założenia leżące u podstaw jakiejkolwiek selekcji na grunt prawa prywatnego, stwierdzić należy, że stosowane dotychczas kwalifikacje dokonywane były według różnych kryteriów i często z bliżej nieokreślonych powodów. Ogólnie system prawa dzieli się na prawo prywatne i publiczne — na podstawie podstawowego kryterium metody regulacji. W literaturze w zasadzie jednomyślnie przyjmuje się, że prawo gospodarcze ze swej natury jest częścią prawa prywatnego. I w zasadzie na tym zgoda się kończy. Czy prawo prywatne należy utożsamiać z prawem cywilnym, czy może prawo prywatne dzieli się na działy (gałęzie?), takie jak prawo cywilne, prawo rodzinne, prawo pracy, prawo regulujące postępowanie cywilne, prawo gospodarcze, czy może wreszcie prawo prywatne dzieli się na prawo materialne (cywilne) i procesowe, a w ramach tego pierwszego pojawiają się dalsze podkategorie — prawo rodzinne, pracy itp. — jest już kwestią sporną ${ }^{2}$. A może prawo cywilne funkcjonuje obok prawa rodzinnego czy pracy, ale zawiera w sobie prawo gospodarcze, jak chcą zwolennicy tak zwanej

${ }^{1}$ Przykładowo abstrakcyjne prawo własności odnoszące się początkowo tylko do przedmiotów świata realnego stało się podstawą konstrukcji oraz opartych na niej norm odnoszących się do tak zwanej własności intelektualnej.

2 Więcej na ten temat zob. S. Włodyka, Prawo handlowe w systemie prawa, [w:] System Prawa Handlowego, t. 1. Część ogólna, red. S. Włodyka, Warszawa 2009, s. 20-48; oraz bardzo interesujące rozważania A. Wiśniewskiego, Stan prywatnego prawa gospodarczego a optymalna wizja kodeksu cywilnego - zagadnienia podmiotowe, PPH 2008, nr 6, s. 1-23. 
teorii monistycznej ${ }^{3}$. Co więcej, nie wiadomo, czy prawo gospodarcze jest gałęzią prawa, działem prawa, dyscypliną prawa, wyspecjalizowaną dyscypliną prawniczą, czy być może - jako pogląd skrajny - wyłącznie kategorią dydaktyczną, powstałą w celu ułatwienia nauczania tej części prawa i stworzenia odpowiednich jednostek dydaktycznych, podręczników itp. We wszystkich tych przypadkach kryteria podziału nie są do końca jasne. Czasami wyodrębnienie opiera się na przyjętej metodzie regulacji, innym razem na podmiotach-adresatach norm albo przedmiocie unormowania. Jako kryterium wskazuje się także kardynalne zasady obowiązujące w danym obszarze, a nawet tak prozaiczne, zdawać by się mogło, przyczyny jak rodzaj i nazwa aktu prawnego, w którym uregulowane zostały zręby danej części regulacji ${ }^{4}$. Przykładowo, według niektórych poglądów uregulowanie - choćby cząstkowe i pobieżne - danej materii w kodeksie nobilituje do nazywania jej gałęzią ${ }^{5}$. Ze stuprocentową pewnością nie można zatem stwierdzić, jakie jest miejsce prawa gospodarczego w systemie prawa i czym to prawo jest. Co gorsza, nie ma także pewności co do prawidłowej zbiorczej nazwy analizowanego zespołu norm, które w tym tekście określane były jako prawo gospodarcze.

\section{O TYM, JAK NAZYWAĆ PRAWO OBROTU KWALIFIKOWANEGO}

Historycznie rzecz ujmując, omawiany zespół norm nazywany był prawem kupieckim (lex mercatoria), prawem handlowym, w Polsce okresu gospodarki nakazowo-rozdzielczej prawem obrotu uspołecznionego, później prawem obrotu gospodarczego, wreszcie prawem gospodarczym prywatnym, a w ostatnich latach do łask znowu powrócił termin ,prawo handlowe”, choć wymiennie stosowany z prawem gospodarczym. Sformułowania te nie zawsze są postrzegane jako równoważne - „prawo handlowe” utożsamia się bardziej z prawem podmiotów (głównie prawem spółek), a prawo gospodarcze z pozostałymi zagadnieniami związanymi z obrotem profesjonalnym — prawem umów, regulacjami dotyczącymi konkurencji, papierów wartościowych itp. W tym kontekście można snuć dalsze rozważania, mianowicie czy prawo handlowe nie jest jedynie wyspecjalizowaną częścią prawa gospodarczego, skupiającą się na regulacji ustroju podmiotów gospodarczych. Wobec umowności konwencji językowej oraz pewnego chaosu terminolo-

3 Teoria monistyczna zakłada tak zwaną jedność prawa cywilnego, w przeciwieństwie do teorii dualistycznej, która każe oddzielnie traktować prawo cywilne, a oddzielnie gospodarcze.

4 Przykładowo we Francji ochrona konsumenta została uregulowana zasadniczo w Code de la consomation, natomiast w innych krajach zwykle jest „rozrzucona” w różnego rodzaju ustawach. Czy jednak znaczy to, że w prawie francuskim istnieje odrębna gałąź prawa konsumenckiego, natomiast w innych krajach nie ma takie kategorii? — zwłaszcza że pod względem zakresu regulacji ze względu na wpływ prawa unijnego wszystkie europejskie porządki prawne są do siebie mocno zbliżone.

${ }^{5}$ Więcej na ten temat zob. J. Helios, W. Jedlecka, Podstawowe pojęcia prawa i prawoznawstwa dla ekonomistów, Wrocław 2015, s. 20 n. 
gicznego byłyby to jednak rozważania jałowe. Ponadto w literaturze zwraca się uwagę na pewną nieadekwatność tego terminu do jego faktycznego desygnatu, obejmującego nie tylko aktywność stricte handlową (to jest zawodową sprzedaż i kupno towarów), lecz także wszelkie inne formy aktywności gospodarczej (produkcja, świadczenie usług, różne formy pośrednictwa finansowego itp.). Zarzut ten zwykle odpierany jest twierdzeniem, że w każdej formie aktywności gospodarczej istnieje jakaś cząstka handlu. Nie wchodząc w dyskusję nad zasadnością tej tezy, trzeba podkreślić, że prawo handlowe wywodzi się z ukształtowanego w średniowieczu prawa stanu kupieckiego. Ówczesne społeczeństwo stanowe podlegało regulacjom prawnym wynikającym z - dzisiejszym językiem rzec by można — kwalifikacji podmiotowej, zwykle pochodnej urodzenia lub funkcji społecznej (na przykład duchowieństwo), a w mniejszym stopniu konkretnego rodzaju wykonywanych zadań. Prawo stanu kupieckiego zatem to prawo ludzi zajmujących się handlem - prawo handlowców, prawo handlowe, którego reguły z czasem rozciągnięto także na producentów oraz innych zawodowych uczestników procesu wymiany dóbr i usług. Geneza i uwarunkowania historyczne pozwalają więc na stosowanie omawianego określenia w szerszym — współczesnym — kontekście. Termin „prawo handlowe” ma bowiem długą tradycję, także — a może przede wszystkim - poza granicami naszego kraju, gdzie używa się takich określeń, jak „handelsrecht”, „droit commercial”, „commercial law”, „,diritto commerciale” itp. W niniejszym opracowaniu sformułowania ,prawo handlowe” $i$,prawo gospodarcze" mają to samo znaczenie i używane są wymiennie już choćby z tego względu, że mowa tu o wyodrębnieniu określonego rodzaju obrotu, a w praktyce częściej mówi się o obrocie gospodarczym (jedno-, dwustronnie gospodarczym) aniżeli obrocie handlowym (jedno-, dwustronnie handlowym).

Z przeprowadzonych dotychczas rozważań wynika, że brakuje zarówno podstaw do precyzyjnego wskazania, czym jest prawo handlowe (gałęzią, działem, dyscypliną itp.), jak i określenia miejsca prawa handlowego w systemie prawa (jest to część prawa cywilnego czy równoważna mu część prawa prywatnego itp.), a w dodatku próżno szukać uznanego i powszechnie akceptowanego terminu określającego ten rodzaj przepisów (prawo handlowe, gospodarcze). Mówiąc o prawie handlowym, poruszamy się zatem po bardzo niedookreślonym obszarze. Jednak dla większości „użytkowników prawa” termin ten nie jest aż tak enigmatyczny, jakby się wydawało w oparciu o dotychczasowe uwagi. Niezależnie od wskazanych wątpliwości natury terminologicznej bez wątpienia prawo handlowe reguluje prywatnoprawne stosunki gospodarcze, a zatem relacje między podmiotami prawa cywilnego (prywatnego), które są w pewien sposób wyspecjalizowane (kwalifikowane). Dlatego prawo handlowe, w przeciwieństwie do tak zwanego obrotu powszechnego, reguluje obrót szczególny. Potrzeba jego wyodrębnienia pojawiła się w związku z koniecznością stworzenia reguł specjalnych umożliwiających lub ułatwiających prowadzenie handlu, co przekładało się na większą efektywność gospodarczą. Dzięki regulacji prawnogospodarczej obrót był szybszy i sprawniej- 
szy, mniej sformalizowany niż tak zwany obrót powszechny, a to między innymi dzięki uwzględnieniu wiedzy i doświadczenia jego uczestników. O ile znane są i pozostają dotychczas aktualne przyczyny wydzielenia obrotu profesjonalnego, o tyle sposób jego dokonania wcale nie jest oczywisty. Pojawia się tu podstawowy dla niniejszego tekstu problem kryteriów wyodrębnienia obrotu, to jest ustalenia, na czym $w$ istocie rzeczy polega i do czego się sprowadza owa cecha kwalifikacyjna.

\section{O KRYTERIACH WYODRĘBNIENIA OBROTU HANDLOWEGO}

Historycznie rzecz ujmując, sprawa była prosta. Prawo stanowe - jak już wspomniano - obowiązywało dany stan, w tym przypadku stan kupiecki, do którego przynależało się z racji urodzenia lub pełnienia określonych funkcji społecznych. W tym też zakresie podlegało się właściwemu sądownictwu stanowemu. Można zatem przyjąć, że główne znaczenie miało kryterium podmiotowe. Było ono także wzbogacane kryterium przedmiotowym, a mianowicie rodzajem czynności podlegającej ocenie prawnej. Z czasem kryterium przedmiotowe miało coraz większe znaczenie. W regulacjach europejskich tradycyjnie systemy oparte na prawie germańskim akcentują aspekty podmiotowe, a systemy czerpiące z romańskiej kultury prawnej (w szczególności prawa francuskiego) w większym stopniu zwracają uwagę na czynniki przedmiotowe. Ten podział, rzec można geograficzny, jest też widoczny w ujęciu historycznym. Im bardziej skomplikowane stosunki gospodarcze i społeczne, tym bardziej potrzebne są szczegółowe normy prawa je regulujące, a to z kolei oznacza, że prawo dostrzega subtelne różnice w charakterze dokonywanych czynności, a więc ich kwalifikacja musi skupić się na elemencie przedmiotowym. Ponadto dawniej człowiek (osoba fizyczna) w znacznie mniejszym stopniu korzystał z wolności - przypisany był do jednej lub zaledwie kilku ściśle zdefiniowanych ról społecznych (przykładowo kupca, męża, ojca), a prawo określało jego sytuację tylko w tych kilku łatwych do odczytania aspektach. Dzisiaj korzystanie z wolności pozwala na występowanie naprzemiennie w wielu rolach (męża, rodzica, ale i przedsiębiorcy, pracownika, konsumenta, wspólnika/udziałowca/akcjonariusza, prezesa albo członka klubu, stowarzyszenia, spółdzielni, partii politycznej itp.). I to wszystko w ramach tej samej osoby fizycznej ${ }^{6}$. Wszystkie te płaszczyzny naszej aktywności są coraz bardziej szczegółowo regulowane prawem, w tym prawem kształtującym obrót gospodarczy, a zatem kwalifikacja dokonywanej czynności musi w coraz większym

6 Średniowieczne prawo nie dostrzegało zasadniczo bytów innych niż osoba fizyczna. Konstrukcja podmiotu prawnego innego niż osoba fizyczna wprawdzie pojawiała się w prawie rzymskim oraz częściowo w średniowieczu, ale daleko tym pojęciom do ukształtowanej ostatecznie w XIX wieku konstrukcji osoby prawnej. 
stopniu uwzględniać kontekst, czyli tak zwane aspekty przedmiotowe. Można więc zaryzykować twierdzenie, że kwalifikacja czynności podlegającej reżimowi obrotu gospodarczego początkowo opierała się niemal wyłącznie na kryteriach podmiotowych, a współcześnie w coraz większym zakresie na kryteriach przedmiotowych. Wydaje się nawet, że kryteria przedmiotowe dziś przeważają oraz — co może być tezą kontrowersyjną — w wielu przypadkach eliminują wręcz kryteria podmiotowe. Idąc dalej, można także sformułować tezę, że w niedalekiej przyszłości kryteria podmiotowe zostaną zredukowane i kwalifikacja czynności prawnej będzie się opierać wyłącznie lub niemal wyłącznie na kryteriach przedmiotowych. Jakkolwiek obrazoburczo to brzmi, analiza tendencji legislacyjnych oraz zachodzących zmian społecznych i gospodarczych wyraźnie sugeruje tego rodzaju obrót spraw. Aby tego dowieść, trzeba przyjrzeć się ewolucji regulacji służących wyodrębnieniu obrotu gospodarczego w ciągu ostatnich lat.

\section{O ZMIANACH W NOMENKLATURZE ORAZ SPOSOBACH WYODRĘBNIANIA PRAWA HANDLOWEGO}

Rozważania zacząć wypada od przyjrzenia się podmiotowi, którego udział W czynności prawnej umożliwia uznanie jej za czynność gospodarczą ${ }^{7}$. W Polsce międzywojennej — ale także wcześniej — posługiwano się pojęciem kupca ${ }^{8}$, które zdefiniowane zostało w kodeksie handlowym z 1934 roku. W powstałym w 1927 roku prawie przemysłowym ${ }^{9}$ używano z kolei słowa „przemysłowiec”. Po drugiej wojnie światowej w socjalistycznej Polsce kwalifikowanego uczestnika obrotu określano mianem jednostki gospodarki uspołecznionej (jgu), ewentualnie jednostki gospodarki nieuspołecznionej (jgn). Terminy te były w powszechnym użyciu, także w kodeksie cywilnym z 1964 roku. W ustawie z 23 grudnia 1988 roku o działalności gospodarczej ${ }^{10}$ wprowadzono swoiste novum - podmiot gospodarczy, który mocno zakorzenił się w polskim języku prawnym i prawniczym, znajdując istotne miejsce $\mathrm{w}$ systemie prawa ${ }^{11}$. Dopiero po niemal dwudziestu latach, w ustawie z dnia 20 sierpnia 1997 roku - Przepisy wprowadzające ustawę o Krajowym Rejestrze Sądowym ${ }^{12}$, posłużono się nowym sformułowaniem:

${ }^{7}$ Choć jak się dalej okaże, samo wystąpienie w stosunku cywilnoprawnym profesjonalisty nie przesądza samo przez się o gospodarczej naturze tej relacji.

8 Zgodnie z art. 2 \& 1 rozporządzenia Prezydenta z 27 czerwca 1934 roku — Kodeks handlowy (Dz.U. z 1934 r. Nr 57, poz. 502).

9 Rozporządzenie Prezydenta RP z 7 czerwca 1927 roku o prawie przemysłowym, Dz.U. Nr 53, poz. 468.

10 Dz.U. Nr 41, poz. 324 z późn. zm.

11 Posługiwały się nim dwie kolejne podstawowe odnośnie do obrotu gospodarczego ustawy publicznoprawne.

12 Dz.U. Nr 121, poz. 770 z późn. zm. 
„przedsiębiorca”. Jednak nie była to ustawa o charakterze ustrojowym w takim stopniu jak kodeks cywilny. Nowelizacja tego ostatniego, dokonana 14 lutego 2003 roku $^{13}$, wprowadziła zarówno nazwę, jak i nową definicję przedsiębiorcy w art. $43^{1} \mathrm{kc}$. Kropkę nad i postawiła regulacja zawarta w ustawie o swobodzie działalności gospodarczej z 2 lipca 2004 roku $^{14}$, która ostatecznie wyeliminowała termin ,podmiot gospodarczy”, zastępując go pojęciem „przedsiębiorca” 15 .

Jak łatwo zauważyć, historia zmian zachodzących w ostatnich latach, jaka dokonała się w zakresie samej tylko nomenklatury, doskonale obrazuje wahania regulacji prawa handlowego oraz jego niespójność, chwiejność fundamentów i nietrwałość założeń aksjologicznych. O tym świadczy także refleksja nad definicją pojęcia profesjonalisty. To ona między innymi - jak już zasygnalizowano — obrazuje erozję regulacji prawa handlowego w ostatnich latach.

Aby nie cofać się zbyt daleko, rozważania warto zacząć od art. 2 § 1 kodeksu handlowego. Zgodnie z jego treścią „kupcem jest ten, kto we własnem imieniu prowadził przedsiębiorstwo zarobkowe”. Nadto po myśli art. 4 ust. 1 „Kupiec, który prowadzi przedsiębiorstwo zarobkowe w większym rozmiarze, jest kupcem rejestrowym". Z kolei wyodrębnienia obrotu handlowego można było dokonać, opierając się na art. 498 i 499. Warto przytoczyć je in extenso:

Art. $498 \S 1$. Czynności prawne kupca związane z prowadzeniem jego przedsiębiorstwa są czynnościami handlowemi. § 2. Domniemywa się, że każda czynność prawna kupca jest czynnością handlową. Art. 499. Jeżeli czynność jest handlowa dla jednej ze stron, stosuje się przepisy prawa handlowego dla obu stron, chyba że prawo stanowi inaczej.

$\mathrm{Z}$ tej prostej regulacji można wyprowadzić kilka wniosków. Po pierwsze była jedna definicja kupca, bardzo prosta i niebudząca wątpliwości interpretacyjnych $^{16}$; po drugie - prawodawca stworzył dwie kategorie kupców (rejestrowy i nierejestrowy ${ }^{17}$ ); po trzecie — zasadniczo wszystkie czynność kupca były czynnościami handlowymi, obowiązywało przy tym domniemanie handlowego charakteru czynności; po czwarte - zasadniczo obrót handlowy zachodził, gdy przynajmniej jedna ze stron czynności była profesjonalistą (kupcem), tym samym w ramach obrotu gospodarczego znajdował się — według dzisiejszego nazewnictwa - tak zwany obrót konsumencki (jednostronnie gospodarczy). Dla ówczesnych stosunków gospodarczych tak określone rudymenty były klarowne, wystarczające i zaspokajały potrzeby. Jak wiadomo, w okresie powojennym ze względu na zmianę ustroju politycznego i gospodarczego nie było potrzeby wracania do pojęć handlowych, co zmieniło się dopiero w roku 1988 i znalazło wyraz we

13 Dz.U. Nr 49, poz. 408.

14 Dz.U. Nr 173, poz. 1809 z późn. zm.

15 Ostatecznie od pojęcia przedsiębiorcy wzięła swoją nazwę ustawa z dnia 6 marca 2018 roku — Prawo przedsiębiorców, Dz.U. poz. 93 z późn. zm.

16 Pomijając kwestię definicji prowadzenia przedsiębiorstwa zarobkowego.

17 Kupiec nierejestrowy zwolniony był z wielu rygorów. 
wspomnianej ustawie o działalności gospodarczej z 23 grudnia (tak zwana ustawa Wilczka) ${ }^{18}$. Przeprowadzane od tego czasu zmiany doprowadziły do tego, że mamy około dwudziestu równolegle funkcjonujących definicji przedsiębiorcy ${ }^{19}$. Definicje te zostały stworzone z powodu różnorodnych potrzeb społecznych czy gospodarczych i należą zarówno do szeroko pojętego obszaru prawa prywatnego, jak i publicznego. Mamy zatem w tym przypadku do czynienia ze sporym chaosem definicyjnym. Głównym przedmiotem zainteresowania powinny być definicje zawarte w prawie przedsiębiorców oraz kodeksie cywilnym ${ }^{20}$. Wykazują one istotne różnice, które są powielane, a nieraz wzmacniane w pozostałych regulacjach.

W Polsce powojennej definicja przedsiębiorcy rozwijała się przede wszystkim w ustawach o charakterze publicznoprawnym, co nie było zjawiskiem korzystnym. Przyczyn tego stanu można doszukiwać się w zaszłościach — w czasach tak zwaną realnego socjalizmu prawo gospodarcze było domeną regulacji publicznoprawnej. Wówczas, mimo rzekomej zasady jedności prawa cywilnego i umiejscowienia w jego ramach także podstawowych przepisów regulujących obrót gospodarczy (wówczas uspołeczniony), gros unormowań zawarto w regulacjach szczegółowych, o całkowicie lub na poły publicznoprawnym charakterze. Dzisiaj już niemal zapomniane różnego rodzaju akty statuujące ogólne warunki sprzedaży, ogólne warunki robót inżynieryjnych są tego dobitnym przykładem. Zresztą i z dzisiejszej perspektywy nie trzeba daleko szukać — zawarta w kodeksie cywilnym regulacja umowy przewozu, jak powszechnie wiadomo, ma zastosowanie do transportu konnego, podczas gdy w zasadzie całość regulacji transportu ulokowana jest w odrębnej ustawie - Prawo przewozowe. To tylko jeden z wielu przykładów ${ }^{21}$. Sprawia to, że śmiało można bronić tezy, że przyjęte w kodeksie cywilnym założenie o jedności prawa cywilnego było $\mathrm{w}$ istocie rzeczy pewnego rodzaju nadużyciem — sztafażem, pod którym krył się faktyczny dualizm prawa prywatnego, wynikający z podstawowej przesłanki wyodrębnienia tego rodzaju obrotu, jakim jest kwalifikacja podmiotowa ${ }^{22}$. Jak wspomniano, reminiscencją czasów minionych w zakresie zarówno pojęć podstawowych (definicyjnych), jak i bardziej szczegółowych unormowań, jest przewaga regulacji publicznoprawnej. Współcześnie, po trzydziestu latach funkcjo-

18 Odchodzącej od tradycyjnego pojęcia „kupiec” i zastępującej je „podmiotem gospodarczym”, przemianowanym ostatecznie na ,przedsiębiorcę”.

19 Fakt ten został dostrzeżony przez wielu autorów; zamiast wielu zob. J. Jacyszyn, Przedsiębiorca w regulacja prawnych, „Edukacja Prawnicza” 2015, nr 4, s. 26 (cz. 1) oraz „Edukacja Prawnicza” 2015, nr 5, s. 42 (cz. 2); a także C. Kosikowski, M. Etel, Nowe prawo działalności gospodarczej, Białystok 2016, zał. nr 2, s. 134.

20 J. Jacyszyn, Wokót pojęcia „przedsiębiorca”, [w:] Ius est ars boni et aequi. Księga pamiątkowa dedykowana Profesorowi Józefowi Frackowiakowi, Wrocław 2018, s. 319.

21 Aby nadmiernie nie mnożyć, jako analogiczne obszary można wskazać oddzielnie uregulowane prawo budowlane, ubezpieczeniowe, bankowe itp.

22 Nieco prześmiewczo parafrazując $\S 2$ ust. 1 kodeksu handlowego, można rzec, że w czasach socjalizmu obowiązywała definicja czysto podmiotowa, zgodnie z którą kupcem jest jednostka gospodarki uspołecznionej. 
nowania w gospodarce wolnorynkowej, coraz bardziej aktualne wydaje się pytanie, czy dalej należy forsować tezę o jedności prawa cywilnego, czy może zgodnie z faktami oraz obiektywnym postrzeganiem rzeczywistości przyjąć, że różnice w obrocie powszechnym i kwalifikowanym są tak znaczne, że nie sposób dalej bronić tez o jednolitości stosowanych w ich ramach rozwiązań. Coraz bardziej palące jest też stawiane już wcześniej pytanie, czy słuszne jest definiowanie przedsiębiorcy w prawie publicznym ${ }^{23}$. Tym bardziej że, jak już zasygnalizowano, różne są potrzeby legislacyjne obu tych gałęzi prawa, a co za tym idzie występują znaczące różnice w samych pojęciach.

Począwszy od wspominanej ustawy Wilczka, w kolejnych regulacjach aż do dzisiaj definicje profesjonalnego uczestnika obrotu miały konstrukcje zbliżone. Wskazywano, że odpowiednio: podmiotem gospodarczym lub przedsiębiorcą jest „osoba fizyczna, osoba prawna lub jednostka organizacyjna niemająca osobowości prawnej" 24 prowadząca działalność gospodarczą. Tę natomiast także różnie definiowano w różnych okresach, choć w sposób zbliżony wskazując, że jest to działalność produkcyjna, usługowa, handlowa, budowlana, wykonywana w celach zarobkowych i na własny rachunek.

\section{O DEFINICJI PRZEDSIĘBIORCY W AKTUALNYM STANIE PRAWNYM JAKO PODSTAWIE DO WYODRĘBNIENIA OBROTU KWALIFIKOWANEGO}

W obowiązującej obecnie regulacji normatywna definicja działalności gospodarczej opiera się na czterach przesłankach — zorganizowanie, zarobkowość, wykonywanie we własnym imieniu oraz ciągłość. We wcześniejszych unormowaniach za działalność gospodarczą uznawano także działalność zawodową. Był to termin bardzo enigmatyczny, nie do końca wiadomo, czy obejmuje on wyłącznie tak zwane wolne zawody, nigdzie w sposób wyczerpujący niezdefiniowane, czy także inne profesje ${ }^{25}$. Zresztą również wymienione wcześniej przesłanki występujące $\mathrm{w}$ definicjach działalności gospodarczej w literaturze budzą wiele istotnych wątpliwości ${ }^{26}$. Tak więc podstawowe w zrozumieniu pojęcia „,przed-

${ }^{23}$ Zob. przykładowo E. Gniewek, [w:] Kodeks cywilny. Komentarz, red. E. Gniewek, Warszawa 2008, s. 98 , teza 1.

${ }^{24}$ Tu też daje się zauważyć wyłom w stosunku do regulacji kodeksu cywilnego, który zgodnie za art. 1 reguluje stosunki cywilnoprawne między osobami fizycznymi i osobami prawnymi. Tak zwana trzecia kategoria podmiotów nie powinna być przez kodeks cywilny dostrzegana. A jednak W art. $43^{1}$ k.c. stwierdza się, że przedsiębiorcą może być także jednostka organizacyjna, o której mowa w art. $33^{1}$ k.c., czyli właśnie ,trzecia kategoria”.

${ }^{25} \mathrm{O}$ wątpliwościach z tym związanych zob. J. Jacyszyn, Wokót pojęcia ..., s. 324 i powołaną tam literaturę.

26 Swoje wątpliwości w tym zakresie formułowali między innymi A. Walszek-Pyzioł, Status prawny przedsiębiorcy $w$ świetle projektu ustawy — prawo dzialalności gospodarczej, PUG 1999, 
siębiorca" oraz wyznaczeniu granic obrotu gospodarczego kategorie pozostają bardzo mgliste, budzą spory i nie są dostatecznie precyzyjne. Podobnie, a nawet gorzej przedstawia się sytuacja w obszarze regulacji prawa prywatnego zawartej w kodeksie cywilnym. W tym przypadku prawodawca zdecydował się na wprowadzenie definicji przedsiębiorcy w księdze pierwszej, co miało być wyrazem docenienia znaczenia pojęcia przedsiębiorca. Przepis, w swej lakonicznej treści, jest prosty. Zgodnie z dodanym nowelizacją z 25 września 2003 roku art. $43^{1}$ k.c. „Przedsiębiorcą jest osoba fizyczna, osoba prawna i jednostka organizacyjna, o której mowa $\mathrm{w}$ art. $33^{1} \S 1$, prowadząca we własnym imieniu działalność gospodarczą lub zawodową". Czym natomiast jest działalność gospodarcza, kodeks już nie wyjaśnia i na gruncie prawa prywatnego odpowiedzi na to pytanie nie znajdziemy. W tym zakresie trzeba było i wciąż niestety posiłkować się trzeba wspomnianą regulacją publiczną — obecnie ustawą Prawo przedsiębiorców i zmierzyć się z wszystkimi jej mankamentami. Co gorsza, kodeks cywilny nie zrezygnował z posługiwania się sformułowaniem „działalność zawodowa”, które jak się obecnie przyjmuje, w zasadzie powinno być albo oddzielnie zdefiniowane (doprecyzowane), albo objęte szerszym pojęciem „działalność gospodarcza”27. Definicja zawarta w kodeksie cywilnym została więc wprowadzona stosunkowo późno (w 2003 roku), zawiera nieprecyzyjne sformułowania i okazuje się niezupełna, gdyż jej sedno pozostaje zdefiniowane w innym akcie o charakterze publiczno-prawnym. Co więc było powodem jej wprowadzenia? Wydaje się, że w dużej mierze motywacją była potrzeba zamanifestowania znaczenia prawa gospodarczego dla obrotu i podkreślenia zasady jedności prawa prywatnego. Był to jednak rodzaj listka figowego, kryjącego brak w obszarze prawa prywatnego umocowania dla prawa gospodarczego prywatnego, któremu przecież przedwojenny legislator poświęcił cały kodeks handlowy. Więcej nawet, warto zauważyć, że omawiana definicja została wprowadzona tą samą ustawą co definicja konsumenta $\mathrm{z}$ art. $22^{1}$ k.c. Daje to podstawy do formułowania tezy, że definicja przedsiębiorcy $\mathrm{w}$ istocie rzeczy służyć miała pewnego rodzaju dopełnieniu regulacji konsumenckich, których wprowadzenie było wymuszone akcesją Polski do struktur unijnych i pospiesznym ,uzupełnianiem” regulacji konsumenckiej. Tego rodzaju tezy były już formułowanie w literaturze. Problem jednak w tym, że definicja przedsiębiorcy na potrzeby prawa ochrony konsumenta ma znikome znaczenie. W pierwotnym brzmieniu definicja konsumenta w ogóle nie odnosiła się do przedsiębiorcy, dopuszczając teoretycznie do powstania obrotu dwustronnie konsumenckiego, co

nr 5, s. 4; C. Kosikowski, Przedsiębiorca w prawie polskim, na tle prawa europejskiego, Warszawa 2013; M. Szydło, Swoboda działalności gospodarczej, Warszawa 2005; W.J. Katner, Prawo dziatalności gospodarczej. Komentarz. Orzecznictwo. Piśmiennictwo, Warszawa 2003.

27 W literaturze wskazuje się jednak, że zakres pojęciowy tego terminu nie całkiem mieści się w pojęciu „działalność gospodarcza”. 
wytykano zresztą jako błąd ${ }^{28}$. Również zawarta w kodeksie cywilnym regulacja tak zwanych klauzul abuzywnych (art. $385^{1}$ i n. k.c.) mówi o kontrahencie konsumenta, a nie o przedsiębiorcy. W ustawach szczegółowych, dotyczących przykładowo kredytu konsumenckiego, przewozu, timesharingu czy sprzedaży na odległość, zawarte są zwykle autonomiczne definicje konsumenta, niekoniecznie zawierające odwołanie do przedsiębiorcy w rozumieniu przepisów ogólnych ${ }^{29}$. Można zatem postawić ostrożną tezę, że bardzo ułomna definicja przedsiębiorcy została wprowadzona do kodeksu cywilnego w celach błahych lub wręcz pozornych. Stwierdzenie to może prowadzić do kolejnego wniosku, że prawo cywilne w ogóle nie potrzebuje definicji przedsiębiorcy (wiele lat radziło sobie bez niej, a i w obecnym kształcie, jak się okazuje, pozostaje ona mało użyteczna). Trzeba sobie zdawać sprawę z tego, że jest to wprawdzie mocna teza, ale jednocześnie zdecydowanie niezupełna. Być może prawo cywilne poradziłoby sobie bez definicji przedsiębiorcy, ale prawo gospodarcze (handlowe) już zdecydowanie nie. I jest to kolejny dowód na potwierdzenie tezy o faktycznym dualizmie prawa prywatnego, a nie forsowanej tezie o rzekomej jedności prawa cywilnego zwolenników koncepcji monistycznej. Zawarcie w kodeksie cywilnym kilku ogólnych przepisów regulujących obrót profesjonalny oraz niepowiązanych wzajemnie i wyraźnie różniących się regulacji szczegółowych ${ }^{30}$ nie oznacza bowiem, że mamy do czynienia z jednorodną i spójną regulacją materii prywatnoprawnej adresowanej do zawodowych i niezawodowych uczestników rynku. Trzeba wyraźnie powiedzieć, że prawo prywatne gospodarcze nie radzi sobie bez solidnej, skrojonej na jego potrzeby definicji przedsiębiorcy, tylko rozpaczliwie poszukuje jej elementów, a także swoistych subdefinicji ${ }^{31} \mathrm{~W}$ ustawach o publicznoprawnym charakterze.

\section{O WPŁYWIE REGULACJI KONSUMENCKICH NA DEFINIOWANIE PRZEDSIĘBIORCY ORAZ WYODRĘBNIANIE OBROTU KWALIFIKOWANEGO}

Dobra definicja oraz aksjomaty danej dyscyplinie są niezbędne, są jej zwornikiem, ustalają system spójnych dogmatów i nie pozwalają na jej erozję, powolny

28 Przykładowo M. Skory, Znaczenie kodeksowej definicji konsumenta dla wyodrębnienia tzw. obrotu konsumenckiego, PPiA 64, 2004; M. Rejdak, Definicja konsumenta w rozumieniu kodeksu cywilnego, „Rejent” 2006, nr 1; M. Chojecka, A.M. Nowak, Ocena dorobku legislacyjnego i orzeczniczego ksztattującego definicję konsumenta na gruncie art. $22^{1}$ kodeksu cywilnego, iKAR 2016, nr 3(5), s. 68.

${ }^{29}$ Występuje tam zwykle odwołanie do zdefiniowanego w większym lub mniejszym stopniu kontrahenta — przewoźnika, organizatora, kredytodawcy itp.

30 Zresztą o różnym, nieraz znikomym, znaczeniu dla obrotu.

31 Pod pojęciem subdefinicji rozumiem definicje wyspecjalizowanych przedsiębiorców (podmiotów gospodarczych), takich jak przewoźnik, bank, ubezpieczyciel itp., które w jakimś stopniu odnoszą się, powołują, odwołują, nawiązują do wyższej kategorii przedsiębiorcy w ogólności. 
rozbiór, zacieranie granic. Na gruncie prawa handlowego ten proces zachodzi od dawna, mimo że liczba regulacji rośnie, traci na tym jej przejrzystość i użyteczność. Nieustanne — pardon la mot — ,grzebanie” przez ustawodawcę w przepisach prowadzi do rozsadzenia systemu prawa gospodarczego, żmudnie rekonstruowanego przez judykaturę oraz iurysprudencję. Nie jest to li tylko problem w dyskusji akademickiej. Opisywana niebezpieczna tendencja prowadzi do poważnych konsekwencji praktycznych. Jasność systemu i czystość opartych na nim konstrukcji pozwala bowiem na odpowiednią kwalifikację czynności, czyli przypisanie znanego stronom, ściśle określonego reżimu prawnego. Widać to zwłaszcza w obrocie konsumenckim, którego rozwój jako coraz bardziej istotnej części obrotu gospodarczego (tak zwany obrót jednostronnie gospodarczy) jest współcześnie jedną z głównych sił napędowych ewolucji prawa gospodarczego w ogólności. Dobrą egzemplifikacją zaprezentowanego nurtu legislacyjnego jest jedna $\mathrm{z}$ ostatnich nowelizacji kodeksu cywilnego, wprowadzająca przepis art. $385^{5}$. Wprawdzie wejście w życie wspomnianego przepisu w związku z sytuacją epidemiczną zostało odroczone do roku 2021, niemniej sama jego zawartość jest bardzo symptomatyczna i wymaga głębszej refleksji. Zgodnie z treścią przytoczonego unormowania:

Przepisy dotyczące konsumenta, zawarte w art. $385^{1}-385^{3}$, stosuje się do osoby fizycznej zawierającej umowę bezpośrednio związaną z jej działalnością gospodarczą, gdy z treści tej umowy wynika, że nie posiada ona dla niej charakteru zawodowego, wynikającego w szczególności z przedmiotu wykonywanej przez nią działalności gospodarczej, udostępnionego na podstawie przepisów o Centralnej Ewidencji i Informacji o Działalności Gospodarczej.

Regulacja ta — mimo jak się wydaje szlachetnych intencji — potęguje zamęt pojęciowy i niepewność prawa ${ }^{32}$. Tworzy bowiem kolejną kategorię przedsiębiorcy, który w pewnych sytuacjach nie jest przedsiębiorcą i może powoływać się na przepisy chroniące konsumentów także w relacji z innym przedsiębiorcą tego samego rodzaju. Przepis (oraz inne o analogicznej mu treści ulokowane w oddzielnych ustawach, na przykład ustawie o ochronie praw konsumentów) tworzy zatem możliwość wydzielenia obrotu dwustronnie konsumenckiego ${ }^{33}$, co pozo-

32 Pomijając inne aspekty, już samo wskazanie zawodowego charakteru może budzić wątpliwość, czy przepis dotyczy tylko przedsiębiorców prowadzących po myśli art. $43^{1}$ k.c. działalność zawodową, czy także tych prowadzących działalność gospodarczą, skoro przepis rozróżnia te dwie kategorie. Odpowiedź na to pytanie wymaga wejścia na bardzo grząski grunt, który przy dobrych definicjach zdecydowanie mógłby być bardziej stabilny.

33 Tak J. Zagrobelny, [w:] Kodeks cywilny. Komentarz, red. A. Gniewek, Warszawa 2019 (Legalis), który w komentarzu do art. 385(5) stwierdza: „Wprowadzone rozwiązanie rezygnuje z jednokierunkowej ochrony, charakterystycznej dla obrotu konsumenckiego, dając każdej ze stron transakcji możliwość powołania się na niedozwolone postanowienia umowne. Tak będzie w przypadku, gdy obie strony umowy będą osobami fizycznymi prowadzącymi działalność podlegającą wpisowi do CEIDG, zaś treścią umowy będzie na przykład sprzedaż zbędnych jednej z nich składników wyposażenia. Zawarcie przez każdą z tych osób umowy związanej z jej działalnością gospodarczą lub zawodową, ale w sposób wykluczający dla nich jej zawodowy charakter pozwoli kwestionować inne postanowienia umowne". 
staje w jawnej sprzeczności z aksjologią przepisów konsumenckich. Dokonany przez prawodawcę zabieg budzi też wątpliwości natury konstytucyjnej — dlaczego tylko osoby fizyczne cechujące się $\mathrm{w}$ danym stosunku brakiem doświadczenia (tak zwaną profan) mogą w relacji z kontrahentem korzystać z nadzwyczajnych środków ochronnych ${ }^{34}$. W tym momencie warto także przypomnieć, że $w$ przeciwieństwie do regulacji zawartej w kodeksie handlowym obecnie obowiązujące prawo nie zawiera domniemania, że czynność przedsiębiorcy (dawniej kupca) jest dokonana $\mathrm{w}$ ramach prowadzonej przez niego działalności (dawniej przedsiębiorstwa $)^{35}$. Prowadzi to do problemów z ustaleniem reżimu prawnego danej czynności, a także onus probandi. Czy kontrahent profana powinien domyślać się, że dana czynność nie pozostaje w bliskim związku z jego działalnością, zwłaszcza wpisaną w CEIDG, czy powinien przy każdej czynności z tak zwanym przedsiębiorcą jednoosobowym weryfikować odnoszące się do niego wpisy w ewidencji, czy być może korzystać z jakiegoś domniemania faktycznego i stosować przepisy ochronne tylko wówczas, gdy zostanie poinformowany przez kontrahenta („ostrzeżony”), że korzysta ze szczególnej ochrony, która mu przysługuje. Tego rodzaju ostrzeżenie stanowiłoby w praktyce uchylenie domniemania faktycznego, że przedsiębiorca jednoosobowy działa w zakresie swojego przedsiębiorstwa. Niestety prawo polskie póki co takiego domniemania nie wprowadziło.

Wątpliwości co do statusu danego podmiotu nie są li tylko wynikiem ostatnich nowelizacji i tkwią w systemie znacznie głębiej. Jak się okazuje, nie każdy formalny przedsiębiorca jest przedsiębiorcą, ale także nie każdy nieprzedsiębiorca podlega regułom obrotu powszechnego. Ten ostatni przypadek zachodzi przecież w odniesieniu do spółek kapitałowych wpisanych do Krajowego Rejestru Sądowego, które nawet mimo nieprowadzenia działalności gospodarczej traktowane są jak przedsiębiorcy.

Na pojawiające się wątpliwości wpływa również utrwalona już skłonność prawodawcy, zarówno krajowego, jak i unijnego ${ }^{36}$, do rozszerzania zakresu stosowania instrumentów ochronnych właściwych stosunkom konsumenckim na inne rodzaje obrotu. Widać przy tym wyraźnie, że — jak już zasygnalizowano — coraz bardziej istotnym elementem wyodrębnienia obrotu gospodarczego, a co za tym idzie przypisania danej transakcji określonego reżimu prawnego, są elementy przedmiotowe. Jest to tendencja stała i występująca w coraz większym nasileniu. Prowadzi to do coraz bardziej kazuistycznych regulacji i jednocześnie niepewności co do sytuacji prawnej

34 Wątpliwość ta pojawiła się zresztą już kilka lat wcześniej, w związku z nowelizacją (dokonaną ustawą z dnia 10 sierpnia 2007 roku) nadającą art. $805 \S 4$ k.c. następujące brzmienie: „Przepisy art. $385^{1}-385^{3}$ stosuje się odpowiednio, jeżeli ubezpieczającym jest osoba fizyczna zawierająca umowę związana bezpośrednio z jej działalnością gospodarczą lub zawodową".

35 Była już o tym mowa.

36 Tak między innymi M. Hesselin, Unfair term in contracts between businesses, [w:] Towards a European Contract Law, red. R. Schulze, J. Stuyck, München 2011, s. 131 n.; V. Roppo, From consumer contracts to asymetric contracts: A trend in European contract law?, „European Review of Contract Law" 5, 2009, nr 3, s. 304 n., za: M. Jagielska, Ile przedsiębiorcy jest w konsumencie?, [w:] Ius est ars boni..., s. 338. 
stron. Warto zatem postawić jeszcze dalej idące pytanie: czy stosowane dotychczas sposoby wyodrębnienia prawa handlowego i klasyfikacji stosunków prawnych przystają do współczesnej rzeczywistości gospodarczej i nie stały się anachroniczne?

\section{O ALTERNATYWNYCH SPOSOBACH WYODRĘBNIANIA OBROTU KWALIFIKOWANEGO}

Być może coraz bardziej skomplikowana metoda wyodrębnienia stosunków gospodarczych (kwalifikowanych), polegająca na stosowaniu kryterium podmiotowego uzupełnionego kryterium przedmiotowym, już się zdezaktualizowała. Czy wyodrębnienie obrotu gospodarczego nie powinno opierać się na badaniu występowania rzeczywistego, a nie tylko formalnego „profesjonalizmu” uczestników obrotu i jednoczesne stosowanie w ramach obrotu kwalifikowanego norm ochronnych wobec słabszej strony stosunku nie powinno opierać się na faktycznych deficytach kontraktowych, a nie tylko formalnym statusie konsumenta? Oczywiście pytanie brzmi — jak w takim razie badać ów profesjonalizm? Wydaje się, że dobrym miernikiem byłby tu stopień zorganizowania danego podmiotu. Tego rodzaju metoda pozwalałaby na wyeliminowanie wielu patologii. Zdarza się bowiem, że nieprowadzący działalności gospodarczej podmiot o wysokim stopniu zorganizowania (na przykład fundacja, stowarzyszenie, związek zawodowy, partia polityczna, samorząd zawodowy) występuje w relacji z przedsiębiorcą jednoosobowym o nikłym stopniu zorganizowania, o zdecydowanie mniejszej sile kontraktowej i wykazującym wobec tego podmiotu istotne deficyty kontraktowe. W takim przypadku prawo zdecydowanie bardziej chroni jednak wspomniany podmiot aniżeli formalnie tylko zawodowego przedsiębiorcę jednoosobowego albo nawet małą spółkę osobową o niedużych zdolnościach organizacyjnych. Kwestia ta jest o tyle interesująca, że we współczesnym świecie wiele międzynarodowych korporacji i niezwykle silnych podmiotów (zwanych nieraz promotorami) celowo tworzy podmioty non profit lub non for profit - pozornie słabe (na przykład organizacje przedsiębiorców, fundacje, stowarzyszenia, a nawet Kościoły), które korzystają z doskonałych narzędzi informatycznych zapewnionych przez promotora, świetnej obsługi prawnej, sprawdzonych relacji biznesowych, realizują wiele zadań swojego promotora, działając na rynku jako swoisty wilk w owczej skórze. Problem ten dostrzec można także w stosunkach zdecydowanie dwustronnie gospodarczych, w których naprzeciw siebie stają bezsprzecznie profesjonaliści, jednak ich zdecydowanie odmienny potencjał gospodarczy nakazywałby prawne wzmocnienie pozycji słabszego z nich. Występujące obecnie podziały na mikroprzedsiębirców, przedsiębiorców małych, średnich i dużych w gruncie rzeczy odwołują się właśnie do wspomnianego kryterium zorganizowania. Nie jest to zresztą niczym nowym. Jak wiadomo, przedwojenny prawodawca również rozróżniał przedsiębiorców rejestrowych i nierejestrowych, przy 
czym ci pierwsi prowadzili przedsiębiorstwo zarobkowe w większym rozmiarze ${ }^{37}$. Być może, dokonując wyodrębnienia obrotu gospodarczego, warto wrócić do tych założeń i sformułować bardziej klarowne zasady pozwalające na wyodrębnienie tych przedsiębiorców, którzy z racji mniejszego stopnia zorganizowania powinni być zwolnieni z pewnych obowiązków ograniczających ich rozwój i jednocześnie korzystać z ochrony przed nadużywaniem przewagi kontraktowej przez kontrahentów ze znacznie od nich większym potencjałem gospodarczym. Czy miałyby to być instrumenty tożsame z tymi, które przysługują konsumentom, jest oczywiście kwestią dyskusyjną. Trzeba mieć bowiem na względzie utrwalone stanowisko organów unijnych, w tym jednolite orzecznictwo TSUE, wskazujące, że ochrona konsumencka przysługiwać może wyłącznie osobie fizycznej. Za konsumenta uważa się osobę fizyczną także wówczas, gdy stopień zorganizowania aktywności danej osoby jest znacznie większy niż przeciętny i nosi pewne cechy organizacji właściwej przedsiębiorcy $^{38}$. Obrazowo można by stwierdzić, że obrót gospodarczy obejmuje współcześnie tak rozległą przestrzeń aktywności ludzkiej, że coraz bardziej powszechnym zjawiskiem jest zmniejszanie zawartości przedsiębiorcy w przedsiębiorcy, a jednocześnie coraz więcej przedsiębiorcy można znaleźć w konsumencie. Uwzględnienie tych zjawisk jest nie lada wyzwaniem dla prawa handlowego. Wyzwaniu temu nie sposób jednak sprostać bez uporządkowania pojęć podstawowych.

\section{WNIOSKI - O POTRZEBIE STWORZENIA NOWYCH ZAŁOŻEŃ DLA SKUTECZNEGO WYODRĘBNIENIA ORAZ EFEKTYWNEGO UNORMOWANIA PRAWA HANDLOWEGO}

Przeprowadzona analiza prowadzi do wniosku, że regulacja obrotu gospodarczego wymaga pilnej interwencji prawodawcy. Trudności wiążą się też z określeniem miejsca prawa handlowego w systemie prawa. Korzystne wydaje się odejście od zasady monizmu i wyodrębnienie prawa handlowego z szeroko pojętego prawa cywilnego z jednoczesnym wzmocnieniem i ujednoliceniem regulacji prywatnoprawnych. Aby stało się to możliwe, należałoby wprowadzić poprawną konstruk-

37 Kryterium podziału stanowił jednak nie tylko rozmiar obrotu, lecz także inne cechy pozwalające na przyjęcie wyższego stopnia zorganizowania danego podmiotu, określone w rozporządzeniu Ministra Przemysłu i Handlu wydanym w porozumieniu z Ministrami Skarbu oraz Rolnictwa i Reform Rolnych (art. 4 § 2 k.h.).

38 Przykładowo, w orzeczeniu TSUE badał, czy korzystanie z konta na Facebooku służącego publikacji książek, wygłaszaniu wykładów, prowadzeniu stron internetowych, organizacji zbiórki datków, nabywaniu roszczeń licznych konsumentów dla dochodzenia ich w postępowaniu sądowym nie oznacza, że należy traktować właściciela profilu jako niekonsumenta. Mimo ostatecznej konkluzji fakt, że Trybunał w ogóle badał omawiane kwestie, świadczy, że rozwój cywilizacyjny doprowadził do sytuacji, w której granice obrotu profesjonalnego istotnie się zacierają. Wyrok Trybunału (trzecia izba) z dnia 25 stycznia 2018 roku, C498/16, Schrems. 
cyjnie i niebudzącą wątpliwości nomenklaturę, popartą ścisłym zdefiniowaniem pojęć podstawowych, takich jak ,przedsiębiorca” oraz „konsument”. Uzdrowienie sytuacji wydaje się łatwiejsze w systemie dualistycznym, w akcie prawa (kodeksie), od którego wymaga się spójności i właściwej, porządnej techniki legislacyjnej. Dotychczasowe doświadczenia sprowadzające się do odkodowywania treści oraz istoty prawa handlowego z porozrzucanych $\mathrm{w}$ wielu regulacjach przepisów, tworzonych chaotycznie, $\mathrm{w}$ różnym czasie, $\mathrm{z}$ różną motywacją, $\mathrm{z}$ powodu nieraz zupełnie odmiennych potrzeb, w praktyce się nie sprawdza. Ze względu na bardzo różnorodny charakter uczestników obrotu gospodarczego konieczne jest także wprowadzenie kategoryzacji przedsiębiorców z uwagi na stopień ich specjalizacji. Jak się wydaje, dobrym kryterium pomocniczym do wprowadzenia tego rodzaju podziałów byłby stopień zorganizowania, który w pewnej formie był już znany polskiemu przedwojennemu prawu handlowemu. Ważne przy tym, aby wprowadzając zmiany, uwzględnić różny potencjał podmiotów gospodarczych oraz zastosować odpowiednie środki służące ochronie przed nadużyciami przewagi kontraktowej większych graczy nad podmiotami słabszymi. Dobrze, aby środki te uwzględniały nie tylko kryteria podmiotowe, ale też przedmiotowe - charakter danej czynności. Ze względu na coraz większe wyspecjalizowanie oraz dostrzegalne zwiększenie potencjału organizacyjnego podmiotów, które tradycyjnie nie były zaliczane do przedsiębiorców, nie powinno uciec uwagi prawodawcy wprowadzenie środków ochronnych przed nadużyciami także ze strony tych rzekomo nieprofesjonalnych uczestników rynku. Podejmowane działania muszą jednak pozostać w zgodzie z założeniami prawa europejskiego, w szczególności dotyczącymi ochrony konsumenta oraz istoty jego definiowania. Nie stoi to jednak na przeszkodzie, aby zgodnie z aktualnymi trendami występującymi w regulacjach europejskich określone mechanizmy ochronne przeszczepiać na grunt stosunków dwustronnie gospodarczych.

\section{ON THE NEED TO VERIFY THE RULES FOR THE SEPARATION OF ECONOMIC (QUALIFIED) TURNOVER}

\section{Summary}

The study addresses the issue of the place of commercial law in the legal system. The analysis, also from a historical perspective, covers various ways of separating commercial law, the names used to define this part of the law and the criteria for the qualification of commercial relations. The further part of the study discusses the impact of consumer regulations on the definition of an entrepreneur and the significance of this for the separation of economic (qualified) trade, as well as the risks associated with this process. In the last part, alternative ways of separating economic turnover are proposed, indicating also the need to unify regulations, to move away from the monistic system and to extend protective mechanisms appropriate for consumer relations also to bilateral economic relations, using the criterion of the degree of organisation of a given entity.

Keywords: commercial law, business law, entrepreneur, consumer, private law monism principle, criteria for the separation of qualified turnover 


\section{BIBLIOGRAFIA}

Chojecka M., Nowak A.M., Ocena dorobku legislacyjnego i orzeczniczego ksztattującego definicje konsumenta na gruncie art. $22^{1}$ kodeksu cywilnego, iKAR 2016, nr 3(5).

Gniewek E., [w:] Kodeks cywilny, Komentarz, red. E. Gniewek, Warszawa 2008.

Helios J., Jedlecka W., Podstawowe pojęcia prawa i prawoznawstwa dla ekonomistów, Wrocław 2015.

Hesselin M., Unfair term in contracts between businesses, [w:] Towards a European Contract Law, red. R. Schulze, J. Stuyck, München 2011.

Jacyszyn J., Przedsiębiorca w regulacja prawnych, cz. 1: „Edukacja Prawnicza” 2015, nr 4, cz. 2: „Edukacja Prawnicza” 2015, nr 5.

Jacyszyn J., Wokót pojęcia „przedsiębiorca”, [w:] Ius est ars boni et aequi. Księga pamiątkowa dedykowana Profesorowi Józefowi Frąckowiakowi, Wrocław 2018.

Jagielska M., Ile przedsiębiorcy jest w konsumencie?, [w:] Ius est ars boni et aequi. Księga pamiątkowa dedykowana Profesorowi Józefowi Frackowiakowi, Wrocław 2018.

Katner W.J., Prawo działalności gospodarczej. Komentarz. Orzecznictwo. Piśmiennictwo, Warszawa 2003.

Kodeks cywilny. Komentarz, red. A. Gniewek, Warszawa 2019.

Kosikowski C., Przedsiębiorca w prawie polskim, na tle prawa europejskiego, Warszawa 2013.

Kosikowski C., Etel M., Nowe prawo działalności gospodarczej, Białystok 2016.

Rejdak M., Definicja konsumenta w rozumieniu kodeksu cywilnego, „Rejent” 2006, nr 1.

Roppo V., From consumer contracts to asymetric contracts: A trend in European contract law?, „European Review of Contract Law” 5, 2009, nr 3.

Skory M., Znaczenie kodeksowej definicji konsumenta dla wyodrębnienia tzw. obrotu konsumenckiego, PPiA 64, 2004.

Szydło M., Swoboda działalności gospodarczej, Warszawa 2005.

Walaszek-Pyzioł A., Status prawny przedsiębiorcy w świetle projektu ustawy - prawo działalności gospodarczej, PUG 1999, nr 5.

Wiśniewski A., Stan prywatnego prawa gospodarczego a optymalna wizja kodeksu cywilnego zagadnienia podmiotowe, PPH 2008, nr 6.

Włodyka S., Prawo handlowe w systemie prawa, [w:] System Prawa Handlowego, t. 1. Część ogólna, red. S. Włodyka, Warszawa 2009. 